\title{
Profesorka Marie Sobotková jubilující
}

\author{
Libor Pavera (Praha)
}

Po bok těm, kteří letos oslavili své životní jubileum, se připojila rovněž slavistka, resp. polonistka a bohemistka prof. PhDr. Marie Sobotková, CSc. Po téměř celou vědeckou dráhu je spjata s olomouckým akademickým prostředním a tamější Univerzitou Palackého. Narodila se 4. 5. 1947 do rodiny Vlasty a Ladislava Kulínských v Ostravě-Zábřehu jako druhé dítě (starší je sestra Milena). Po maturitě na střední všeobecně vzdělávací škole v Ostravě-Vítkovicích zahájila v roce 1965 svá vysokoškolská studia na Filozofické fakultě Univerzity Palackého v Olomouci (obor čeština - polština). Na fakultě v té době působilo několik výrazných osobností české polonistiky i bohemistiky: patřili k nim lingvisté Jiří Damborský a Edvard Lotko, literární badatelky Hana Jechová (později, po sňatku s francouzským komparatistou známá více jako Voisine-Jechová) a Krystyna Kardyni-Pelikánová na straně jedné, lingvista Jiří Daňhelka a literární vědci Oldřich Králík, Jiří Skalička a Eduard Petrů na straně druhé. Vědecký rádius Marie Sobotkové je tak v pozdějším období rozkročen hlavně mezi polonistikou a literárněvědnou bohemistikou. Samozřejmě jejich součástí je rovněž glottodidaktika, nezbytná složka předávání filologického vědění prostřednictvím školy mladším generacím.

V průběhu studií Marii Kulínskou, provdanou Sobotkovou (manželem je historik a spisovatel Jan Sobotka), přitahovala starší období české literatury. Pracovníci bohemistiky očekávali, stejně jako mladá absolventka, že následovat bude její příprava ve vědecké aspirantuře, avšak normalizační dění rozhodlo jinak: dcera vyloučeného člena strany nemohla být přijata do vědecké aspirantury, změnila se rovněž struktura olomoucké bohemistiky a polonistiky, někteří pracovníci byli nuceni z fakulty odejít nebo byli penzionováni. Tucet let učila na odborném učilišti, mezitím v roce 1973 získala doktorát filozofie na základě rigorózní práce Bartoloméj Paprocký z Hlohol a Paprocké Viole a Šimon Lomnický z Budče (Umělecko-ideový rozbor jejich mravně výchovné tvorby). Již z uskutečněného rigorózního řízení je patrné, že Marie Sobotková zůstávala v kontaktu s fakultou a jejími pracovníky. Na fakultu se vrátila až v roce 1982 na místo literárněvědného polonisty a bohemisty s orientací na starší českou literaturu. Vědeckou aspiranturu směla nicméně zahájit až po revolučních událostech na přelomu osmdesátých a devadesátých let 20. století a kandidátskou práci České memoáry 17. stoleti (Žánrová analýza memoárových textů) obhájila v roce 1993 na Masarykově univerzitě v Brně. V roce 1995 proběhlo v Olomouci její habilitační řízení (spis Autor - text - adresát v memoárech 17. století (Studie z české, polské a slovenské literatury 17. století) vyšel knižně v roce 1996). V roce 2003 byla jmenována profesorkou.

Cesta Marie Sobotkové ke starší literatuře ani k polonistickým studiím nebyla př́ímočará a jednoduchá, nicméně zdá se svědčit o skutečném badatelčině zájmu o obor. Podtrhuje to rovněž počet publikovaných článků a studií (celkově přes devadesát), vysokoškolských 
příruček nebo edic z jejích výzkumů. Zejména v oblasti starší české literatury je nutno si povšimnout některých badatelčiných prací. Navázala jimi jednak souhlasně na starší bádání, ale jednak starší bádání kriticky přehlédla a opravila a zároveň svými originálními zjištěními přispěla naší paleoslavistice. Zvláště pak tam, kde její bohemistická témata zabíhají již do problematiky polonistické a snoubí se s ní: přesah směrem ke kontextu slovanskému i neslovanskému bývá u našich bohemistů tradičně řídký (již od dob strukturalistů), proto je nutno jej v pracích Marie Sobotkové ocenit, docenit a podtrhnout.

$\mathrm{V}$ olomouckém akademickém centru měla nač navazovat. V poválečném období, když v roce 1946 došlo k obnovení olomouckého vysokého učení, věnoval se v Olomouci výuce starší české literatury Antonín Škarka, jeden z nadaných žáků brněnského paleobohemisty Stanislava Součka. Medievalistickým tématům zasvětil značnou část svého badatelského usilování rovněž Oldřich Králík, robustní vypravěč šaldovského střihu, který je více známý jako znalec díla Březinova, Bezručova nebo Čapkova, nicméně nejstarším legendám českého původu a jejich filiacím i některým českým historickým postavám věnoval pozornost hned v deseti knižních pracích. Starší literatuře se však nevěnovali v Olomouci jen ti, kdo předmět př́mo přednášeli na fakultě: pěstovali ho rovněž germanista a obecný jazykovědec Pavel Trost, neobyčejně sečtělý, vzdělaný a rozhleděný po světové filologii (z Olomouce odešel do Prahy), Jiří Daňhelka, známý svými kvalitními edicemi staročeského materiálu (zvláště tvorby Mistra Jana Husa), anglista Ladislav Cejp, studující podoby středověké alegorie, apod. Při vědecké výchově se Marie Sobotková setkávala nejčastěji s Eduardem Petrů, který nejprve působil v olomoucké Vědecké knihovně v oddělení starých rukopisů a tisků, teprve později v šedesátých letech trvale přešel na bohemistickou katedru olomoucké univerzity, kde se naplno začal věnovat výzkumu středověké, renesanční a barokní literatury (zvláště olomouckému humanismu) a teorii literatury. Ale vlivy nebývají jen jednosměrné: Petrů se prostřednictvím seminářů $\mathrm{s}$ vědeckými aspiranty a kolegy dovídal o zahraniční literatuře předmětu (např. prostřednictvím polonistů o genologii, což je $\mathrm{v}$ jeho odborných pracích zvláště patrné od let sedmdesátých a osmdesátých), sám byl ovlivněn zejména matematickými metodami v literární vědě a veden snahou učinit vědu o literatuře exaktní vědou obdobnou přírodním vědám. I když východiskem analýzy byl pro Eduarda Petrů konkrétní textový materiál (sám byl rovněž editorem), vždy směřoval $\mathrm{k}$ obecnému závěru a zobecnění. Je to dobře patrné z trojice prací, které vyšly v širokém časovém rozpětí, ale lze je označit za volnou trilogii (Zašifrovaná skutečnost, 1972; Vzrušujici skutečnost, 1984; Zrcadlo skutečnosti, 2002).

V pracích Marie Sobotkové je nutno pozitivně ocenit smysl pro historicitu bádání a dotyk s konkrétním materiálem - úsilí jít si pro východisko svého uvažování „ad fontes“. Využívala zpravidla na starší literaturu vcelku bohatých fondů Vědecké knihovny v Olomouci. Jiným charakteristickým rysem její odborné práce je sledování vazeb Olomouce a jejího bezprostředního okolí na polské prostředí. Je to pochopitelně dáno jejím dvojdomým univerzitním školením bohemistickým a polonistickým. Probíraná problematika je tak u Marie Sobotkové s prospěchem viděna zpravidla v polsko-českých a česko-polských souvislostech, př́padně v kontextu slovanském, a tedy srovnávacím.

Její knižní práce Autor, text, adresát v českých, polských a slovenských memoárech 17. století (1996) je vyústěním zájmu o memoárovou literaturu ve třech západních slovanských 
literaturách. Může posloužit jako př́íklad precizně a ve všech směrech poctivě vytvořené vědecké práce v oboru literární vědy. Studium memoárové literatury viděla Sobotková jako perspektivní pro výzkum z několika důvodů. Tato tvorba jednak nebyla dřivěǰším bádáním studována jako „čistě“ literární, ale spiše bývala považována za př́ivažek literatury stojící na samém okraji systému, žánrový komplex tak zpravidla vypadával z žánrového modelu starší české literatury a jednotlivých jejích kulturněhistorických celků, jednak může dnešnímu člověku ukázat cestu autorů ve snahách podat v textech realistické reflexe člověka a světa, který ho obklopuje: „Z diachronního hlediska se pak jevi právě tyto žánrové formy jako ,nosné, tematicky i formálně inspirativni, a lze je považovat za prédobraz budoucích vyprávěni , malých př́běhư prīistich generaci..." (s. 9).

Lze pozorovat, že vedle hlediska žánrového, na které byli čtenáři studií a edic Marie Sobotkové zvyklí, přibylo v knize výrazně ještě hledisko komunikační. Právě směrem k literární komunikaci, chápané jako jednota tvorby a recepce, se od let šedesátých 20. století v československém kontextu ubírala skupina badatelů uskupených kolem Kabinetu literárnej komunikácie a experimentálnej metodiky př̀i Pedagogické fakultě v Nitře, jež více méně nezávisle na světovém bádání došla $\mathrm{k}$ výsledkům a metodám analýzy textu, jaký je znám např. z prací kostnické Rezeptionsästhetik (H. R. Jauß, R. Lachmannová aj.). Rovněž ty Marie Sobotková s prospěchem využívala. Ze slovenských badatelů se vrací nejen k pracím Mikovým, Plutkovým a jiných z „nitranské školy“, ale rovněž k pracím polské provenience - starší (R. Ingarden, S. Skwarczyńské aj.), ale i k dobově současné.

Její práce o autobiografických textech 17 . století má uvedeny hypotézy a cíle, $\mathrm{k}$ nimž chce dospět, exkurz terminologický, nutný při studiu žánrů ve starších literaturách pro ujasnění žánrového půdorysu a podstaty útvaru v dobovém literárním životě a systému literatury, část analytickou, kontrastivní i syntetickou s výhledy, kam je možno směřovat další badatelské usilování. V monografii se Marie Sobotková zaměřila celkem na 34 memoárové texty z literatury české (16), slovenské (4) a polské (15) napsané v „národních“ jazycích, přičemž neopomněla zdůraznit, že je v budoucnu třeba přihlédnout rovněž $\mathrm{k}$ literatuře psané latinsky nebo německy. Marie Sobotková došla $\mathrm{k}$ cenným výsledkům, např. o dvou, resp. v polské literatuře o třech vrstvách autobiografických textů (autobiografické texty referující a beletrizující, eventuálně beletrizované). Všímá si tak jevu, který A. Škarka druhdy nazval tendencí beletrizační ve starší české literatuře a hledal její projevy: Sobotková podrobuje texty $\mathrm{v}$ analýze nejen rozboru tvarově-stavebnému (žánrovému), ale i ideově-komunikačnímu, estetickému a antropologickému. Modifikace textů v jednotlivých národních literaturách ji pak přivádějí ke konstatování výsledných diferencí v podobě autobiografických textů 17. století: v českých přibývá postupů běžných $\mathrm{v}$ umělecké literatuře, $\mathrm{v}$ polských se uplatňuje ještě výraznější rozvolnění a sklon k uvolněnému vyprávění (později přešlo ve specifický žánr, tzv. gawędu), ve slovenské se projevuje lyrizovaná próza a sentimentalismus.

Monografie z roku 1996 shrnuje sumu poznání o autorech, ke kterým se Marie Sobotková vyjadřovala $\mathrm{v}$ drobnějších studiích a recenzích v předcházejícím období. Po monografii následuje období, kdy se její badatelská činnost rozbíhá po časově širším horizontu, do hloubky a šîrky směřuje jak $\mathrm{v}$ oblasti druhově-žánrové a tematické, tak z hlediska časového a prostorového. Metodicky využívá backround, který získávala od doby studia 
na olomoucké univerzitě, ale samozřejmě ho dále rozvíjí a tříbí v souladu s vývojem a proměnami oboru.

Studie a úvahy, které vznikají po vydání monografie o autobiografických (memoárových) textech, soustředila Marie Sobotková v souboru nazvaném Studie z české a polské literatury s podtitulem Pět stoletív historii česko-polských literárnich souvislostí(2002). Ve výběru do něj zahrnula své stati z rozmezí pětadvaceti let. Všechny prošly pečlivou revizí a tam, kde to bylo účelné, stylistickou i věcnou korekturou. Dotýkají se literaturní kultury v časovém rozsahu pěti století (od renesance do současnosti), z hlediska prostorového se pak nejvíce orientují na literaturu dvou sousedících slovanských národů - českou a polskou, avšak badatelka přihlíží rovněž k jiným evropským literaturám a překlenuje tak možnou parciálnost a areálovost.

Šlo o výběr zdařilý, nebot na jedné straně kniha jako celek ukazovala vzájemnou propojenost a reciproční kontakty mezi českým a polským literárním prostředím a obapolnou recepci a na straně druhé postihovala rozdílnou dynamiku obou literatur. Evoluční proměny v české a v polské literatuře sledované ve studiích Sobotkové na jednotlivých jevech v textech, ale i na př́ikladech již vyhraněných a vnitřně celistvých literárních období, proudů a skupin, se v širším časovém záběru pěti století ukazují být daleko zřetelnější, profilovanější a čitelnější, než kdyby byly sledovány v literárních celcích časově i prostorově užších. Ač na jedné straně jde až o minuciózní sondy do známějšího, méně povědomého i zcela neznámého literárního materiálu, o sondy, které na první pohled mohou působit staticky, na straně druhé je výsledný obraz neustále dáván do pohybu: propojením materiálově podložených analýz s pasážemi obecného dosahu, které jednotlivinu zasazují do širšího kontextu a literární proces nahlížejí v širokém komplexu filozofie literárních dějin. Badatelce se tak dařilo zobecňovat získané poznatky a vřazovat je do širších souvislostí slovanských literatur. Přispěla tím nejen bohemistickému a polonistickému bádání, ale obecněji slavistickým literárněvědným disciplínám. Tato pozitiva lze vztáhnout stejně na její stati s literárněhistorickým podložím, tak i na glottodidaktické a informační (zvláště oddíl VI. - Zakres działań dydaktycznych: ksztatcenie polonistów w środowisku czeskim).

Badatelka však při analýzách neustává pouze na textech literárních, jak to bylo příznačné pro monografii z roku 1996, ale všímá si tu podnětně rovněž ostatních druhů umění. Zvláště se zaměřila na film a zdařile interpretovala intersémiotické přepisy některých vybraných textů klasické i novější polské literatury do filmové podoby; ve statích sledovala funkčnost a smysl intersémiotických přepisů typu literatura $\rightarrow$ film - tak tomu bylo např. ve studii analyzující filmový přepis Mickiewiczových Dziadů u Tadeusza Konwickiego. Nevyhýbala se konečně ani nejnovějším trendům ve sféře mediálních technologií (uplatňovaných v oblasti česko-polských kulturních vztahů, např. ve stati Internet jako środek nowoczesnego ksztatcenia polonistów w środowisku czeskim), ani problematice rozvoje bohemistických studií v Polsku a polonistických studií v českých zemích, zejména pak v olomouckém polonistickém centru, které po několik let sama pomáhala budovat a spoluutvářet (Uwagi o nauczaniu filologii polskiej jako obcej (FPJO) na polonistyce w Otomuńcu), včetně doktorského studijního programu.

I probírané pragmatické otázky souvisejí s budováním česko-polských mostů v oblasti literatury a literární vědy a svědčí o badatelčině systematickém a soustavném promýšlení 
otázek budoucího směřování české polonistiky, která má letitou a slavnou tradici, již nelze opouštět: naopak bude to v 21. století právě návrat k tradici a vytváření nových vizí a utopií, které mohou překonat současnou strnulou fázi - fázi zahleděnosti do přítomna a stavu „tady a ted'“. Pěstování kultu současnosti by vedlo pouze do slepé uličky: poukazují na to prospektikové i všichni ti, kdo se obírají megatrendy pro 21. století.

Jinou oblastí, jíž Marie Sobotková věnovala náležitou pozornost, je literární kultura druhé poloviny 18. století, kdy baroko se již jako stylová formace vyžívá a nastupuje osvícenství a klasicismus. Sem patří její materiálově cenné studie o Hugo Kołłątajovi (v jubilejním roce 2017 spolu s Jiřím Fialou vydává monografii, zčásti věnovanou Kołłątajově internaci v Olomouci a Josefově) nebo o polské účasti na českém literárním vývoji v sedmdesátých a osmdesátých letech 18. století.

Opomenout není možné ani její činnost popularizační. Zejména spolu s fakultním kolegou Jiřím Fialou se Marie Sobotková věnovala projevům moravského folkloru: při zpřístupňování nahrávek hudebního souboru Mucica Folklorica prostřednictvím hudebních alb.

Nelze nepřipomenout její četnou účast na mezinárodních konferencích a badatelské výjezdy (Varšava, Krakov, Katovice, Lodž, Vratislav, Lublin, Opole, Čenstochová, tam působila v roce 2016 jako hostující profesorka). Přednášela rovněž dějiny polské literatury na Filozofické fakultě Ostravské univerzity v Ostravě, během zimního semestru 2016/2017 vedla v Ústavu slavistiky Filozofické fakulty Masarykovy univerzity Brno kurz na téma Polské stopy v české kulturni krajině. Aktivně se zapojuje do dění spolkového (Lite-

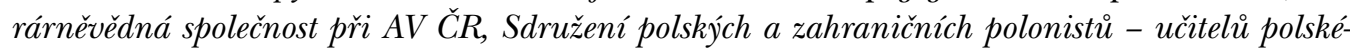
ho jazyka a kultury Bristol, České asociace slavistů, Slavistické společnosti Franka Wollmana), je členkou redakcí odborných periodik, vede grantové úlohy apod. Nevšední pracovní nasazení Marie Sobotkové vedlo zřejmě prezidenta Polské republiky Aleksandra Kwaśniewského k udění rytířského kř́iže Řádu za zásluhy o Polskou republiku. V roce 2013 byla letošní jubilantce udělena Cena POLONICUM určená pro nejlepší zahraniční učitele polského jazyka a kultury. V jubilejním roce jí Slavistická společnost Franka Wollmana udělila Pamětní list za celoživotní přínos české slavistice. ${ }^{1}$

prof. PhDr. Libor Pavera, CSc.

Konšelská 426/25

18000 Praha 8, Česká republika

I.pavera@seznam.cz

1 K připomenutí badatelčina jubilea vyšel sborník, do něhož přispěli Jiří Fiala, Libor Pavera, Ivo Pospíšil a Michał Hanczakowski. Součástí knihy je bibliografie prací Marie Sobotkové. Srov. Polonistka a bohemistka Marie Sobotková : sbornik k životnímu jubileu. Red. Libor Pavera. Praha: Verbum, 2017. 61 s. 
